\title{
Disturbed Lipid Metabolism in Patients with Subclinical Hypothyroidism: Effect of L-Thyroxine Therapy
}

\author{
Shiro Miura, Makoto Ittaka, Hiroshi Yoshimura*, Shinji Kitahama, Nobuhiko Fukasawa, Yoshito Kawakami, \\ Shinichi Sakurai, Michiyuki Urabe, Yoshiki Sakatsume, Kunihiko Ito* and Jun IshiI
}

\begin{abstract}
To evaluate whether patients with subclinical hypothyroidism have a disturbance in lipid metabolism, and whether supplemental $L$-thyroxine $\left(L-T_{4}\right)$ therapy would improve their lipid parameters, we measured serum levels of thyroid hormones, TSH and lipid parameters in 34 patients with subclinical hypothyroidism before and 2 months after treatment with $L-T_{4}$. Before treatment, patients with subclinical hypothyroidism had elevated serum low density lipoprotein cholesterol (LDL-C) concentrations compared with control subjects $(P<0.05)$. Overall, $L_{-}-T_{4}$ therapy significantly decreased the serum level of TSH $(P<0.01)$, total cholesterol $(\mathrm{TC} ; \mathrm{P}<0.02)$, high density lipoprotein cholesterol $(\mathrm{P}<0.02)$, LDL-C $(\mathrm{P}<0.05)$, and the ratio of apolipoprotein $B$ to apolipoprotein $\mathrm{A1}(\mathrm{P}<\mathbf{0 . 0 5})$. Lipid values in patients with basal serum $\mathrm{TSH}$ levels below $10 \mathrm{mU} /$ I were not affected by $L-T_{4}$ therapy, whereas serum levels of $T C$ and LDL-C decreases significantly $(P<0.01)$ in patients with serum TSH levels above $10 \mathrm{mU} / 1$. Thus, the $\mathrm{L}-\mathrm{T}_{4}$ treatment appears to have a preventive effect on the disturbance of lipid metabolism in patients with subclinical hypothyroidism, especially in patients with serum TSH levels above $10 \mathrm{mU} / \mathrm{l}$.
\end{abstract}

(Internal Medicien 33: 413-417, 1994)

Key words: latent hypothyroidism, lipid disturbance

\section{Introduction}

Subclinical hypothyroidism is commonly found in patients with Graves' disease after radioiodine therapy or surgery, it may also occur spontaneously as a result of autoimmune thyroiditis (1). Several reports show that patients with subclinical hypothyroidism have a disturbed lipid metabolism, including elevated serum levels of total cholesterol (TC) and low density lipoprotein (LDL) fraction (2-4) and decreased serum levels of high density lipoprotein fraction (HDL) (5). Such changes are generally recognized as risk factors for atherosclerosis and coronary heart disease (6-8). Indeed, patients with subclinical hypothyroidism have been reported to have a higher risk of coronary heart disease (2, 3, 9-11).

We investigated the change in serum lipid parameters in patients with subclinical hypothyroidism before and after $\mathrm{L}_{-} \mathrm{T}_{4}$ therapy. We also compared the effects of ${\mathrm{L}-\mathrm{T}_{4}}_{4}$ therapy in patients according to basal TSH levels.

\section{Patients and Methods}

We evaluated 34 patients with subclinical hypothyroidism who had remained stable for more than 6 months. There were 8 males and 26 females aged $47.5 \pm 12.5$ (mean \pm SD). Subclinical hypothyroidism was defined as an elevated basal serum TSH $(>3.3 \mathrm{mU} / \mathrm{l})$ in conjunction with a normal serum free $\mathrm{T}_{3}(3.8-$ $9.2 \mathrm{pmol} / \mathrm{l})$ or free $\mathrm{T}_{4}(9.6-25.0 \mathrm{pmol} / \mathrm{l})$ value. Among the 34 patients studied, 25 patients had Graves' disease after radioiodine therapy and 9 had Hashimoto's thyroiditis. These patients were compared with 24 euthyroid subjects (15 with Hashimoto's thyroiditis and 9 with thyroid nodule) who were matched for age, sex, and body mass index. Patients with a history of coronary heart disease and those with any disorders that could influence lipid metabolism (such as diabetes mellitus, chronic liver dysfunction, nephrotic syndrome, or pancreatitis) were excluded. Thyroid function and lipid parameters were assessed in both patients and controls. Patients were treated with $\mathrm{L}-\mathrm{T}_{4}$ for 2 months with a mean dose of $67.7 \pm 24.6 \mu \mathrm{g} / \mathrm{day}$. Afterward, baseline measurements were repeated. Dietary and smoking habits did not change during the study period.

From the Fourth Department of Internal Medicine, Saitama Medical School, Saitama and *Ito Hospital, Tokyo

Received for publication November 8, 1993; Accepted for publication May 16, 1994

Reprint requests should be addressed to Dr. Shiro Miura, or Makoto Iitaka, the Fourth Department of Internal Medicine, Saitama Medical School, Morohongo 38, Moroyama-machi, Iruma-gun, Saitama 350-04 
Venous samples were drawn after an overnight fast, and assays were performed within 48 hours. Serum free $T_{3}$ and free $\mathrm{T}_{4}$ concentrations were measured by radioimmunoassay (Amerlex $\mathrm{FT}_{3}$ RIA and $\mathrm{FT}_{4}$ RIA kit; Amersham Japan Co., Tokyo, Japan). TSH levels were measured by a highly sensitive radioimmunometric assay (Riagnost hTSH; Behring Co., Marburg, Germany), which has a detection limit of $0.03 \mathrm{mU} / \mathrm{l}$ and a normal range of 0.35 to $3.3 \mathrm{mU} / \mathrm{l}$ (mean $\pm 2 \mathrm{SD}$ of normal subjects in our laboratory). The concentrations of serum TC, triglycerides (TG), and HDL-C were measured enzymatically (Daiichikagaku Co., Tokyo, Japan) using an automated analyzer (Hitachi 7450; Hitachi Co., Tokyo, Japan). Values for LDL-C were estimated by using the formula of Friedwald et al (12). Apolipoprotein (Apo) A1 and B levels were determined by immunonephelometry (Daiichikagaku Co., Tokyo, Japan). All data are presented as the mean \pm SD. Statistical analysis was performed using the paired t-test $(n>20)$, paired Wilcoxon's test $(\mathrm{n}<20)$ and unpaired t-test (patients versus controls). A level of $\mathrm{P}<0.05$ was accepted as statistically significant.

\section{Results}

Table 1 shows the result of thyroid function tests in controls and in patients with subclinical hypothyroidism before and after ${\mathrm{L}-\mathrm{T}_{4}}_{4}$ therapy. Before treatment, serum TSH and free $\mathrm{T}_{4}$ levels were significantly elevated in patients with subclinical hypothyroidism, whereas free $\mathrm{T}_{3}$ levels did not differ from those of controls. After L- $\mathrm{T}_{4}$ therapy, serum TSH levels were normalized $(\mathrm{P}<0.01)$ compared with pretreatment values, and serum free $T_{4}$ levels were significantly increased $(\mathrm{P}<0.01)$. No significant change was noted in serum free $T_{3}$ values before and after $\mathrm{L}-\mathrm{T}_{4}$ therapy.

Table 2 shows the changes in lipid parameters. Before $\mathrm{L}-\mathrm{T}_{4}$ treatment, serum levels of LDL-C were significantly elevated $(\mathrm{P}<0.05)$ in patients with subclinical hypothyroidism compared with euthyroid control subjects. After treatment, serum TC, HDL-C, and LDL-C levels and the Apo B/A1 ratio were significantly decreased from baseline $(\mathrm{P}<0.02$ for $\mathrm{TC}$ and $\mathrm{HDL}$ -

Table 1. Mean $( \pm S D)$ Results of Thyroid Function Tests in Euthyroid Controls and in Patients with Subclinical Hypothyroidism before and after L- $\mathrm{T}_{4}$ Therapy

\begin{tabular}{lccc}
\hline & $\begin{array}{c}\text { Euthyroid } \\
\text { controls } \\
(\mathrm{n}=24)\end{array}$ & $\begin{array}{c}\text { Subclinical hypothyroidism } \\
(\mathrm{n}=34)\end{array}$ \\
\hline bGE & $44.9 \pm 8.26$ & $47.5 \pm 12.5$ \\
BMI $\left\{\mathrm{kg} /(\mathrm{m})^{2}\right\}$ & $22.2 \pm 1.98$ & $23.3 \pm 2.47$ \\
TSH $(\mathrm{mU} / \mathrm{l})$ & $1.41 \pm 0.98$ & $20.13 \pm 19.38^{\mathrm{a})}$ & $3.05 \pm 2.25^{\mathrm{b})}$ \\
Free $\mathrm{T}_{3}(\mathrm{pmol} / \mathrm{l})$ & $5.90 \pm 1.13$ & $5.91 \pm 1.17$ & $6.14 \pm 1.01$ \\
Free $\mathrm{T}_{4}(\mathrm{pmol} / \mathrm{l})$ & $16.4 \pm 2.31$ & $13.5 \pm 3.21^{\mathrm{a})}$ & $19.6 \pm 4.49^{\mathrm{b})}$ \\
\hline
\end{tabular}

${ }^{\text {a) }} \mathrm{P}<0.01$ vs euthyroid controls. ${ }^{\text {b) }} \mathrm{P}<0.01$ vs before $\mathrm{L}-\mathrm{T}_{4}$ therapy.
Table 2. Mean $( \pm S D)$ Lipid Parameters in Euthyroid Controls and in Patients with Subclinical Hypothyroidism before and after $\mathrm{L}-\mathrm{T}_{4}$ Therapy

\begin{tabular}{|c|c|c|c|}
\hline & \multirow{2}{*}{$\begin{array}{l}\text { Euthyroid } \\
\text { controls } \\
(n=24)\end{array}$} & \multicolumn{2}{|c|}{$\begin{array}{l}\text { Subclinical hypothyroidism } \\
\qquad(\mathrm{n}=34)\end{array}$} \\
\hline & & before & after \\
\hline TC (mmol/l) & $5.66 \pm 0.86$ & $6.08 \pm 1.24$ & $5.74 \pm 1.25^{\mathrm{a})}$ \\
\hline $\mathrm{TG}(\mathrm{mmol} / \mathrm{l})$ & $1.72 \pm 0.82$ & $1.36 \pm 0.97$ & $1.36 \pm 0.64$ \\
\hline HDL-C (mmol/l) & $1.51 \pm 0.30$ & $1.50 \pm 0.39^{\mathrm{d})}$ & $1.41 \pm 0.37^{\mathrm{a})}$ \\
\hline LDL-C (mmol/l) & $3.37 \pm 0.82$ & $4.03 \pm 1.20^{(\mathrm{cd})}$ & $3.78 \pm 1.22^{b)}$ \\
\hline LDL-C/HDL-C & $2.30 \pm 0.68$ & $2.85 \pm 1.24^{\mathrm{d})}$ & $2.82 \pm 1.04$ \\
\hline Apo Al (mg/dl) & $141.7 \pm 23.7$ & $143.9 \pm 25.6$ & $144.8 \pm 29.1$ \\
\hline Apo B (mg/dl) & $97.3 \pm 21.6$ & $102.0 \pm 24.6$ & $98.7 \pm 28.1$ \\
\hline Apo B/A1 & $0.70 \pm 0.16$ & $0.76 \pm 0.27$ & $0.73 \pm 0.25^{b)}$ \\
\hline
\end{tabular}

${ }^{\text {a) }} \mathrm{P}<0.02$ vs before $\mathrm{L}-\mathrm{T}_{4}$ therapy. ${ }^{\text {b) }} \mathrm{P}<0.05$ vs before $\mathrm{L}-\mathrm{T}_{4}$ therapy. ${ }^{\mathrm{c}} \mathrm{P}<0.05$ vs euthyroid controls. ${ }^{\text {d) }} \mathrm{n}=33$.

Table 3. Mean $( \pm \mathrm{SD})$ Thyroid Hormone Levels and Lipid Parameters in Patients with Subclinical Hypothyroidism, Grouped by Basal Serum TSH Levels, before and after L-T 4 Therapy

\begin{tabular}{|c|c|c|c|c|}
\hline & \multicolumn{2}{|c|}{$\begin{array}{c}\mathrm{TSH}<10 \mathrm{mU} / \mathrm{l} \\
\quad(\mathrm{n}=15)\end{array}$} & \multicolumn{2}{|c|}{$\begin{array}{c}\mathrm{TSH}>10 \mathrm{mU} / \mathrm{l} \\
\quad(\mathrm{n}=19)\end{array}$} \\
\hline & before & after & before & after \\
\hline $\begin{array}{l}\text { Free } \mathrm{T}_{3} \\
(\mathrm{pmol} / \mathrm{l})\end{array}$ & $3.98 \pm 0.90$ & $3.98 \pm 0.59$ & $3.75 \pm 0.64$ & $4.02 \pm 0.72$ \\
\hline $\begin{array}{l}\text { Free } T_{4} \\
(\mathrm{pmol} / \mathrm{l})\end{array}$ & $1.11 \pm 0.27$ & $1.43 \pm 0.27^{\mathrm{a})}$ & $1.00 \pm 0.22$ & $1.61 \pm 0.39^{\mathrm{a})}$ \\
\hline $\begin{array}{c}\mathrm{TC} \\
(\mathrm{mmol} / \mathrm{l})\end{array}$ & $5.94 \pm 0.97$ & $5.81 \pm 1.20$ & $6.19 \pm 1.43$ & $5.67 \pm 1.32^{\mathrm{a})}$ \\
\hline $\begin{array}{c}\mathrm{TG} \\
(\mathrm{mmol} / \mathrm{l})\end{array}$ & $1.77 \pm 1.29$ & $1.46 \pm 0.73$ & $1.04 \pm 0.42$ & $1.27 \pm 0.57$ \\
\hline $\begin{array}{l}\text { HDL-C } \\
(\mathrm{mmol} / \mathrm{l})\end{array}$ & $1.48 \pm 0.30$ & $1.39 \pm 0.39$ & $1.42 \pm 0.56^{b)}$ & $1.36 \pm 0.48$ \\
\hline $\begin{array}{l}\text { LDL-C } \\
(\mathrm{mmol} / \mathrm{l})\end{array}$ & $3.74 \pm 0.96$ & $3.90 \pm 1.00$ & $4.26 \pm 1.34^{\mathrm{b})}$ & $3.50 \pm 1.59^{\mathrm{a})}$ \\
\hline LDL-C/HDL-C & $2.64 \pm 0.8$ & $2.96 \pm 1.1$ & $2.81 \pm 1.35^{\mathrm{b})}$ & $2.62 \pm 1.45$ \\
\hline $\begin{array}{l}\text { Apo Al } \\
(\mathrm{mg} / \mathrm{dl})\end{array}$ & $144.5 \pm 18.7$ & $141.4 \pm 23.1$ & $142.4 \pm 31.7$ & $146.0 \pm 36.1$ \\
\hline $\begin{array}{l}\text { Apo B } \\
(\mathrm{mg} / \mathrm{dl})\end{array}$ & $103.5 \pm 23.4$ & $102.6 \pm 30.3$ & $99.4 \pm 25.3$ & $95.7 \pm 25.3$ \\
\hline Apo B/A1 & $0.73 \pm 0.20$ & $0.73 \pm 0.18$ & $0.77 \pm 0.31$ & $0.73 \pm 0.28$ \\
\hline
\end{tabular}

${ }^{\text {a) }} \mathrm{P}<0.01$ vs before $\mathrm{L}-\mathrm{T}_{4}$ therapy. ${ }^{\text {b) }} \mathrm{n}=18$. 


\section{C, $\mathrm{P}<0.05$ for LDL-C and Apo B/A1).}

Patients with subclinical hypothyroidism were then divided into two groups according to their treatment dose of $\mathrm{L}-\mathrm{T}_{4}$ and their basal serum TSH levels using the highly sensitive TSH assay. As shown in Table 3 , serum free $\mathrm{T}_{4}$ levels were significantly $(\mathrm{P}<0.01)$ increased after $\mathrm{L}-\mathrm{T}_{4}$ therapy regardless of basal serum TSH levels, while serum free $\mathrm{T}_{3}$ levels were not changed with $\mathrm{L}-\mathrm{T}_{4}$ therapy in either groups. There was no significant difference in free $T_{3}$, free $T_{4}$ or TSH levels after $L-T_{4}$ therapy between patients treated with $50 \mu \mathrm{g}$ per day of $\mathrm{L}_{-} \mathrm{T}_{4}$ and those with $100 \mu \mathrm{g}$ per day of $\mathrm{L}-\mathrm{T}_{4}$. There was no significant difference in all lipid parameters in patients treated with $\mathrm{L}_{-} \mathrm{T}_{4}$ of $50 \mu \mathrm{g}$ per day $(n=24)$. However, serum levels of TC and LDL-C in patients treated with $\mathrm{L}_{-} \mathrm{T}_{4}$ of $100 \mu \mathrm{g}$ per day $(\mathrm{n}=10)$ were significantly decreased (TC: $6.32 \pm 1.18$ to $5.72 \pm 0.91 \mathrm{pmol} / \mathrm{l}$; $\mathrm{P}<0.05$, LDL-C: $4.46 \pm 0.93$ to $3.81 \pm 0.91 ; \mathrm{P}<0.01$ ), while serum HDL-C and Apo B/A1 levels were not affected with $100 \mu \mathrm{g}$ per day of $\mathrm{L}-\mathrm{T}_{4}$. The lipid parameters in patients with serum TSH levels below $10 \mathrm{mU} / \mathrm{l}(\mathrm{n}=15)$ were not affected by $\mathrm{L}-\mathrm{T}_{4}$ therapy. However, serum levels of TC and LDL-C were significantly $(\mathrm{P}<0.01)$ decreased after $\mathrm{L}-\mathrm{T}_{4}$ therapy in patients with serum TSH levels above $10 \mathrm{mU} / \mathrm{l}(\mathrm{n}=19)$. The difference in serum TC and LDL-C levels before and after L-T $\mathrm{T}_{4}$ therapy was more prominent in patients with higher serum TSH levels (Table 4). However, there was no significant correlation between TSH levels and either the serum TC or the LDL-C level ( $r=0.20$ and $\mathrm{r}=0.31$, respectively). Analysis of the results obtained from preand post-treatment samples revealed no significant correlation between serum TSH levels and the serum TC or LDL-C levels $(\mathrm{r}=0.193$ and $\mathrm{r}=0.244$, respectively). No patients lost more than $2 \mathrm{~kg}$ of body weight or developed angina pectoris during $\mathrm{L}-\mathrm{T}_{4}$ therapy.

Table 4. Changes of Mean $( \pm S D)$ Serum TC and LDL-C Levels in Euthyroid Controls and in Patients with Subclinical Hypothyroidism before and after L-T ${ }_{4}$ Therapy: Effect of Serum TSH Levels on Serum TC or LDL-C Levels

\begin{tabular}{lcccc}
\hline & \multicolumn{2}{c}{ TC (mmol/l) } & \multicolumn{2}{c}{ LDL-C (mmol/l) } \\
& before & after & before & after \\
\hline $\begin{array}{l}\text { Euthyroid } \\
\text { controls }(\mathrm{n}=24)\end{array}$ & $5.67 \pm 0.86$ & - & $3.37 \pm 0.82$ & - \\
$\begin{array}{l}\text { Subclinical } \\
\text { hypothyroidism } \\
(\mathrm{n}=34)\end{array}$ & $6.08 \pm 1.24$ & $5.74 \pm 1.25^{\mathrm{b})}$ & $4.03 \pm 1.20^{\mathrm{d})}$ & $3.78 \pm 1.22^{\mathrm{c})}$ \\
$\begin{array}{l}\mathrm{TSH}<10 \mathrm{mU} / 1 \\
(\mathrm{n}=15)\end{array}$ & $5.94 \pm 0.98$ & $5.81 \pm 1.20$ & $3.74 \pm 0.96$ & $3.88 \pm 1.00$ \\
$\begin{array}{l}\mathrm{TSH}>10 \mathrm{mU} / 1 \\
(\mathrm{n}=19)\end{array}$ & $6.19 \pm 1.43$ & $5.67 \pm 1.32$ & $4.26 \pm 1.34^{\mathrm{e}) \mathrm{g})}$ & $3.50 \pm 1.59^{\mathrm{a})}$ \\
& & & & \\
$\begin{array}{l}\mathrm{TSH}>20 \mathrm{mU} / \mathrm{l} \\
(\mathrm{n}=11)\end{array}$ & $6.35 \pm 1.07^{\mathrm{f})}$ & $5.54 \pm 0.92^{\mathrm{a})}$ & $4.43 \pm 0.93^{\mathrm{d}) \mathrm{h})}$ & $3.55 \pm 1.04^{\mathrm{a})}$ \\
\hline
\end{tabular}

${ }^{\text {a) }} \mathrm{P}<0.01$ vs before $\mathrm{L}-\mathrm{T}_{4}$ therapy. ${ }^{\text {b) }} \mathrm{P}<0.02$ vs before $\mathrm{L}-\mathrm{T}_{4}$ therapy. ${ }^{\mathrm{c}} \mathrm{P}<0.05$ vs before $\mathrm{L}-\mathrm{T}_{4}$ therapy ${ }^{\mathrm{d})} \mathrm{P}<0.01$ vs euthyroid controls. ${ }^{\text {e) }} \mathrm{P}<0.02$ vs euthyroid controls. ${ }^{f)} \mathrm{P}<0.05$ vs euthyroid controls. ${ }^{\text {g) }} \mathrm{n}=18$. ${ }^{\mathrm{h})} \mathrm{n}=10$.

\section{Discussion}

Hypercholesterolemia is a well established feature of overt hypothyroidism (13-15). However, the results of serum lipid determinations are controversial in subclinical hypothyroidism. Some authors $(3,16)$ found a higher serum TC level while others $(5,17)$ did not. Although Althaus et al $(5)$ found no difference in serum TC levels between patients with subclinical hypothyroidism and controls, serum LDL fractions were elevated and serum HDL fractions were diminished in the patients compared with healthy controls matched for age, sex, and body mass index. Caron et al demonstrated that ${\mathrm{L}-\mathrm{T}_{4}}_{4}$ administration to patients with subclinical hypothyroidism restöred normal serum levels of HDL-C, whereas serum TC and Apo $\mathrm{A} 1, \mathrm{~A} 2$, and B levels were unchanged (17). On the other hand, Arem and Wolfgang found no change in serum HDL-C levels, although serum TC, LDL-C, and Apo B levels were decreased during $\mathrm{L}_{-} \mathrm{T}_{4}$ therapy (18). These conflicting results might be due to differences in the patients studied and the definition of subclinical hypothyroidism (a highly sensitive TSH assay system was not used in these studies or in the definition).

In the present investigation, the serum levels of LDL-C which are considered to be an important cardiovascular risk factor (7-8) were significantly increased in patients with subclinical hypothyroidism. After L- $\mathrm{T}_{4}$ therapy for 2 months, serum levels of TC, HDL-C, LDL-C levels and Apo B/A1 ratio were significantly decreased. Although serum levels of HDL$\mathrm{C}$ were decreased after $\mathrm{L}_{-} \mathrm{T}_{4}$ therapy, they were still higher than $1.03 \mathrm{mmol} / \mathrm{l}(40 \mathrm{mg} / \mathrm{dl})$ in 28 of 33 patients \{ mean: $1.41 \pm 0.37$ $\mathrm{mmol} / \mathrm{l}(54.6 \pm 14.4 \mathrm{mg} / \mathrm{dl})\}$, and serum levels of Apo A1 were unchanged (Table 2, Fig. 1). Furthermore, serum HDL-C and Apo A1 levels were not significantly decreased, even in patients with serum TSH levels above $10 \mathrm{mU} / \mathrm{l}$ (Table 3 ). The present data suggest that subclinical hypothyroidism is accompanied by an elevation of atherogenic lipid components, and $\mathrm{L}^{-\mathrm{T}_{4}}$ therapy improves the deteriorated lipid metabolism in these patients.

It has been reported that patients with hypothyroidism show a decreased turnover of ${ }^{131}$ I-labeled LDL-C (19), it was returned to normal after ${\mathrm{L}-\mathrm{T}_{4}}_{4}$ therapy predominantly due to an increase in cholesterol clearance. Thompson et al reported that the elevation of serum levels of LDL-C in patients with hypothyroidism was caused by both impaired receptor-mediated and non-receptor dependent pathways of LDL clearance, which was improved after the treatment with $\mathrm{L}_{-} \mathrm{T}_{4}(20)$. Davidson et al reported that hepatic Apo A1, A4 and B- 100 synthesis rates are markedly decreased in hypothyroid animals. When hypothyroid rats are made hyperthyroid, the protein and mRNA levels of ApoA1 and A4 are markedly increased. On the other hand, Apo B-100 synthesis became undetectable without alteration in Apo B mRNA levels (21). Patients with subclinical hypothyroidism appears to have the same defect in lipid metabolism since patients with higher serum TSH levels had higher serum LDL-C levels and the decrease in serum LDL-C levels was more prominent after ${\mathrm{L}-\mathrm{T}_{4}}_{4}$ therapy in those patients.

To determine whether $\mathrm{L}-\mathrm{T}_{4}$ is beneficial for all patients with 

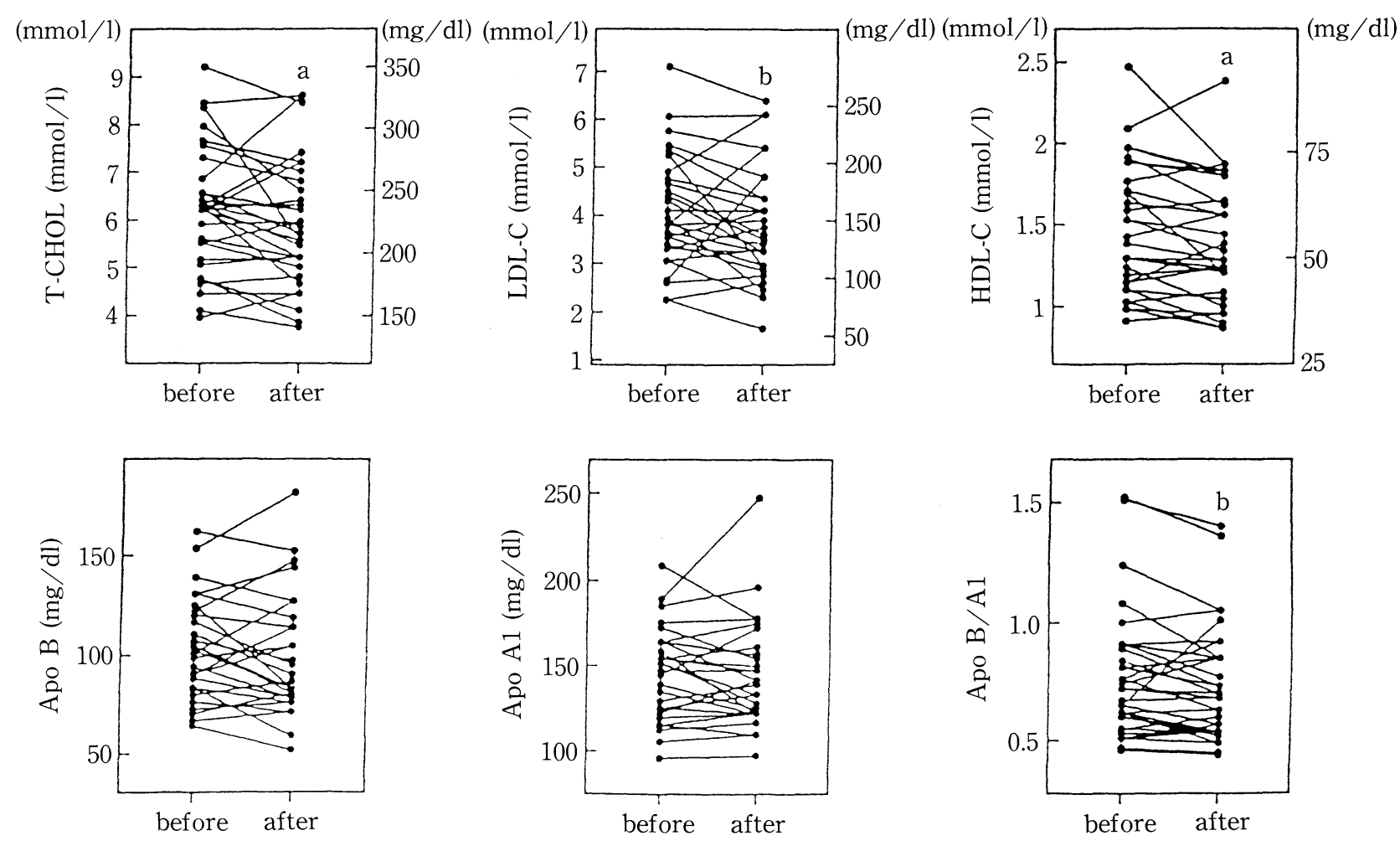

Fig. 1. Serum lipid levels in individual patients with subclinical hypothyroidism before and after $\mathrm{L}-\mathrm{T}_{4}$ therapy. a: $\mathrm{p}<0.02$ vs before $\mathrm{L}-\mathrm{T}_{4}$ therapy, $\mathrm{b}$ : $\mathrm{p}<0.05$ vs before $\mathrm{L}-\mathrm{T}_{4}$ therapy.

subclinical hypothyroidism, we divided the patients according to basal serum TSH levels. In the group with serum TSH levels above $10 \mathrm{mU} / \mathrm{l}, 14$ of 19 patients had serum TC levels above $5.18 \mathrm{mmol} / \mathrm{l}(200 \mathrm{mg} / \mathrm{dl})$ and 11 of 18 patients had serum LDL$\mathrm{C}$ levels above $4.14 \mathrm{mmol} / \mathrm{l}(160 \mathrm{mg} / \mathrm{dl})$; patients with these values are considered to require dietary therapy or medication to prevent coronary heart disease $(22,23)$. After $\mathrm{L}-\mathrm{T}_{4}$ therapy for 2 months, serum TC and LDL-C levels decreased in 14 patients. Although there was no significant correlation between serum TSH levels and lipid parameters, patients with higher serum TSH levels tended to have higher serum TC or LDL-C levels, and $\mathrm{L}_{-} \mathrm{T}_{4}$ therapy markedly decreased those values (Table 4). This suggests that the effect of hypothyroidism in the lipid metabolism is more marked in patients with higher serum TSH levels, such that the improvement of lipid parameters after $\mathrm{L}-\mathrm{T}_{4}$ therapy became more prominent in these patients. This is consistent with the fact that thre was a significant correlation between serum TSH levels and TC, LDL-C and Apo B levels in patients with overt hypothyroidism $(\mathrm{r}=0.791, \mathrm{r}=0.739, \mathrm{r}=0.741$, respectively: unpublished data). On the other hand, when patients with subclinical hypothyroidism were treated with large amounts of $\mathrm{L}-\mathrm{T}_{4}$ to suppress the serum TSH levels below the normal range, there was a significant correlation between serum TSH and LDL-C levels in 11 post-menoposal female (24). However, from the practical therapeutic point of view, it is not recommended to administer large amounts of $\mathrm{L}-\mathrm{T}_{4}$ to suppress TSH levels below normal for a long term, since it may have adverse effects on the bone or heart (25-27).

Although additional longitudinal controlled studies are required to determine whether the effect of $\mathrm{L}_{-} \mathrm{T}_{4}$ on lipid metabolism alters the prognosis of atherosclerosis and coronary heart disease, the present results suggest that patients with subclinical hypothyroidism who have serum TSH levels above $10 \mathrm{mU} / \mathrm{l}$ should be treated with $\mathrm{L}_{-} \mathrm{T}_{4}$, if they have hypercholesterolemia or elevated serum LDL-C levels.

\section{References}

1) Anonymous. Subclinical hypothyroidism (Editorial). Lancet i: 251, 1986.

2) Bastenie PA, Bonnys M, Vanhaelst L, Neve P, Staquet, M. Preclinical hypothyroidism: A risk factor for coronary heart disease. Lancet i: 203, 1971.

3) Dean JW, Fowler PBS. Exaggerated responsiveness to thyrotrophin releasing hormone: a risk factor in women with coronary artery disease. Br Med J 290: 1555, 1985.

4) Series JJ, Biggart EM, O’Reilly D St J, Packard CJ, Shepherd J. Thyroid dysfunction and hypercholesterolaemia in the general population of Glasgow, Scotland. Clin Chim Acta 172: 217, 1988.

5) Althaus BU, Staub JJ, Ryff-De Leche A, Oberhansli A, Stahelin HB. LDL/HDL-changes in subclinical hypothyroidism: possible risk factors for coronary heart disease. Clin Endocrinol (OXF) 28: 157, 1988.

6) Goldstein JL, Hazzard WR, Schrott HG, et al. Hyperlipidemia in coronary disease. J Clin Invest 52: 1533, 1973.

7) Kannel WB, Castelli WP, Gordon T. Cholesterol in the prediction of atherosclerotic disease. Ann Intern Med 90: 85, 1979.

8) Barbir M, Wile D, Trayner I, Aber VR, Thompson GR. High prevalence 


\section{Lipid Disturbance in Subclinical Hypothyroidism}

of hypertriglyceridaemia and apolipoprotein abnormalities in coronary artery disease. Br Heart J 60: 397, 1988.

9) Bastenie PA, Vanhaelst L. Coronary-artery disease in hypothyroidism. Lancet ii: 1221, 1967.

10) Bastenie PA, Goldstein J, Vanhaelst L, Smets Ph. Asymptomatic autoimmune thyroiditis and coronary heart disease. Lancet ii: 155, 1977.

11) Tieche M, Lupi GA, Gutzwiller F, Grob PJ, Studer H, Burgi H. Borderline low thyroid function and thyroid autoimmunity: Risk factor for coronary heart disease? Br Heart J 46: 202, 1981.

12) Friedwald WT, Levy RI, Fredrickson DS. Estimation of the concentration of low-density lipoprotein cholesterol in plasma without use of the preparative centrifuge. Clin Chem 18: 499, 1972.

13) Peters J, Man EB. The significance of serum cholesterol in thyroid disease. J Clin Invest 29: 1, 1950.

14) Malmros H, Swahn B. Lipid metabolism in myxoedema. Acta Med Scand 145: 361, 1953.

15) Kutty KM, Bryant DG, Farid NR. Serum lipid in hypothyroidism: reevaluation. J Clin Endocrinol Metab 46: 55, 1978.

16) Fowler PBS, Swale J, Andrews H. Hypercholesterolemia in borderline hypothyroidism: Stage of premyxoedema. Lancet ii: 488, 1970.

17) Caron Ph, Calazel C, Parra HJ, Hoff M, Louvet JP. Decreased HDL cholesterol in subclinical hypothyroidism: The effect of L-thyroxine therapy. Clin Endocrinol (OXF) 33: 519, 1990.

18) Arem R, Wolfgang P. Lipoprotein and apoprotein level in subclinical hypothyroidism. Arch Intern Med 150: 2097, 1990.

19) Walton KW, Scott PJ, Dykes PW, Davis JW. The significance of alteration in serum lipids in thyroid dysfunction, II Alteration of the metabolism and turnover of ${ }^{131} \mathrm{I}$-low-density lipoproteins in hypothyroidism and thyrotoxicosis. Clin Sci 29: 217, 1965.

20) Thompson GR, Soutar AK, Spengel FA, Jadhav A, Gavigan SJP, Myant NB. Defect of receptor-mediated low density lipoprotein catabolism in homozygous familial hypercholesterolemia and hypothyroidism in vivo. Proc Natl Acad Sci USA 59: 2591, 1981.

21) Davidson NO, Carlos RC, Drewek MJ, Parmer TG. Apolipoprotein gene expression in the rat is regulated in a tissue-specific manner by thyroid hormone. J Lipid Res 29: 1511, 1988.

22) Shepherd J, Betteridge DJ, Durrington P, et al. Strategies for reducing coronary heart disease and desirable limits for blood lipid concentrations: guidelines of the British Hyperlipidemia Association. Br Med J 295: $1245,1987$.

23) National Cholesterol Education Program. Report of the expert panelon detection, evaluation, and treatment of high blood cholesterol in adults. Arch Intern Med 148: 36, 1988.

24) Frankryn JA, Daykin J, Betteridge J, et al. Thyroxine replacement therapy and circulating lipid concentrations. Clin Endocrinol (OXF) 38: 453, 1993.

25) Diamond T, Nery L, Hales I. A therapeutic dilemma; Suppressive doses of thyroxine significantly reduce bone mineral measurements in both premenoposal and post menoposal women with thyroid carcinoma. J Clin Endocrinol Metab 72: 1184, 1990.

26) Toh SH, Brown PH. Bone mineral content in hypothyroid male patients with hormone replacement; A 3-year study. J Bone Mineral Res 5: 463, 1990.

27) Biondi B, Fazio S, Carella C, et al. Cardiac effects of long term thyrotropinsuppressive therapy with levothyroxine. J Clin Endocrinol Metab 77: 334, 1993. 